Check for updates

Stockholm

Cite this as: BMJ2021;373:n905 http://dx.doi.org/10.1136/bmj.n905 Published: 06 April 2021

\section{Covid-19: Italy makes vaccination mandatory for healthcare workers}

\section{Marta Paterlini}

Italy has become the first country in Europe to make vaccination against covid-19 mandatory for healthcare workers, as its government approved an emergency decree on 1 April to contain a third wave of the disease. Health professionals who refuse to have the vaccine will have the option to be transferred to duties that do not risk spreading the virus or to be suspended without pay for as much as a year.

Italy is one of the European countries to have been hit hardest by covid-19, with over 3.5 million cases and 108839 (3\%) deaths. ${ }^{1}$ Several small outbreaks of cases in hospitals and elderly care homes, which were found to have been started by caregivers who rejected the vaccine, led to the emergency legislation.

The Order of Doctors, Surgeons and Orthodontists (FNOMCeO), which backs the new decree, says that most doctors, nurses, and dentists in Italy have already received or will soon receive the covid-19 vaccine. Only about one in 10 ooo medical staff is refusing to be vaccinated, it said, and greater reluctance is seen among less skilled workers in medical facilities and care homes.

In Lombardy, the northern Italian region worst hit by covid-19, 6-10\% of healthcare workers have not joined the vaccination plan, while in the southern region of Puglia the regional authority estimates that proportion to be $10-15 \%$.

\section{Ethical obligation}

Whether the decree is constitutional is still not clear, and many commentators believe that future legal cases regarding vaccination are likely.

Laura Palazzani, deputy vice president of the National Bioethics Committee, said, "Vaccines are an ethical obligation for health professionals: their professional duty to treat the sick obliges them to avoid transmitting the infection, to operate in safe conditions, and to provide reliable information on the significance of vaccines for the protection of public health.” The committee generally supports voluntary vaccination but has said that it accepts the value of mandatory vaccination of healthcare workers when necessary.

Filippo Anelli, president of FNOMCeO, said that the government should have gone further and made the legal procedure to suspend unvaccinated workers smoother and faster.

The decree also protects doctors who administer the vaccines from criminal liability, as long as the shot has been carried out in accordance with the Ministry of Health's instructions. Some doctors have become hesitant to vaccinate people, as several doctors were investigated for manslaughter after a 43 year old navy official died shortly after being given the vaccine last month.

Anelli said that he would have also liked to see greater legal protection in the decree for doctors treating patients with covid-19.

1 Paterlini M. On the front lines of coronavirus: the Italian response to covid-19. BMJ2020;368:m1065. doi: 10.1136/bmj.m1065 pmid: 32179517

This article is made freely available for use in accordance with BMJ's website terms and conditions for the duration of the covid-19 pandemic or until otherwise determined by BMJ. You may use, download and print the article for any lawful, non-commercial purpose (including text and data mining) provided that all copyright notices and trade marks are retained. 